\title{
Aerodynamic stability and turbulent sensible-heat flux over a melting ice surface, the Greenland ice sheet
}

\author{
Roger J. Braithwaite \\ Department of Geography, University of Manchester, Manchester M13 9PL, England
}

\begin{abstract}
The turbulent sensible-heat flux to a melting ice surface is calculated from wind speed and air temperature at $2 \mathrm{~m}$ over the ice surface, assuming a certain wind profile with the appropriate surface roughness. The aerodynamic stability of the boundary layer over melting ice is examined by comparing sensible-heat fluxes for logarithmic and log-linear wind profiles, where the logarithmic profile is strictly valid only for neutral conditions. Increasing stability reduces the sensible-heat flux to the glacier surface and introduces a non-linear relation between heat flux and air temperature. The stability effect is greatest at low wind speeds and fairly small at the high wind speeds that are common over the ice sheet. Earlier estimates of ablation by energy-balance modelling may be too large due to neglect of stability but this was almost offset by using a surface roughness that was too small. The log-linear wind profile should be used in future energy-balance models to take account of stability but more research is needed on the parameters of the profile, as well as on the surface roughness.
\end{abstract}

\section{NOTATION}

A Dimensionless bulk-transfer coefficient

$A_{\mathrm{N}} \quad$ As above, neutral conditions

$A_{\mathrm{S}} \quad$ As above, stable conditions

$b \quad$ Atmospheric pressure $(\mathrm{Pa})$

$b_{0} \quad$ Standard atmospheric pressure $\left(1.013 \times 10^{5} \mathrm{~Pa}\right)$

$c_{\mathrm{p}} \quad$ Specific heat of air, constant pressure $1005 \mathrm{~J}$ $\mathrm{kg}^{-1} \operatorname{deg}^{-1}$ )

$g \quad$ Gravitational acceleration $\left(9.81 \mathrm{~m} \mathrm{~s}^{-2}\right)$

$H$ Turbulent sensible-heat flux $\left(\mathrm{W} \mathrm{m}^{-2}\right)$

$H_{\mathrm{N}}$ As above, neutral conditions $\left(\mathrm{W} \mathrm{m}^{-2}\right)$

$H_{\mathrm{S}}$ As above, stable conditions $\left(\mathrm{W} \mathrm{m}^{-2}\right)$

$k \quad$ von Karman's constant (0.41)

$K_{\mathrm{H}} \quad$ Coefficient of eddy diffusivity $\left(\mathrm{m}^{2} \mathrm{~s}^{-1}\right)$

$K_{\mathrm{M}}$ Coefficient of eddy viscosity $\left(\mathrm{m}^{2} \mathrm{~s}^{-1}\right)$

$L$ Obukhov scale length (m)

$N \quad$ Sample size (d)

$R$ Product-moment correlation coefficient

$\mathrm{Ri}$ Bulk Richardson number

$T$ Air temperature at $2 \mathrm{~m}$ above glacier (deg)

$T_{\mathrm{K}} \quad$ Absolute air temperature $(\mathrm{K})$

$T_{0} \quad$ Surface temperature of glacier $(0 \mathrm{deg})$

$u \quad$ Wind speed $2 \mathrm{~m}$ above glacier $\left(\mathrm{m} \mathrm{s}^{-1}\right)$

$u_{*} \quad$ Friction velocity $\left(\mathrm{m} \mathrm{s}^{-1}\right)$

$z \quad$ Instrument height $(2 \mathrm{~m})$

$z_{0} \quad$ Surface roughness for sensible-heat flux $\left(1.7 \times 10^{-4} \mathrm{~m}\right)$

$z_{0 \mathrm{U}} \quad$ Surface roughness for wind speed $\left(2 \times 10^{3} \mathrm{~m}\right)$

$z_{0 \mathrm{~T}}$ Surface roughness for temperature $\left(6 \times 10^{-6} \mathrm{~m}\right)$

$\alpha \quad$ Empirical parameter for sensible-heat flux (5)

$\alpha_{\mathrm{U}} \quad$ As above, $\log$-linear wind profile

$\alpha_{\mathrm{T}} \quad$ As above, $\log$-linear temperature profile

$\beta \quad$ Empirical heat-transfer coefficient $\left(\mathrm{W} \mathrm{m}^{-2} \mathrm{deg}^{-1}\right)$
$\Gamma \quad$ Adiabatic lapse rate $\left(9.8 \times 10^{-3} \mathrm{deg} \mathrm{m}^{-1}\right)$

$\rho \quad$ Density of air $\left(\mathrm{kg} \mathrm{m}^{-3}\right)$

$\rho_{0} \quad$ Standard density of air $\left(1.29 \mathrm{~kg} \mathrm{~m}^{-3}\right)$

$\tau \quad$ Turbulent shear stress at glacier surface $\left(\mathrm{kg} \mathrm{m}^{-1} \mathrm{~s}^{-2}\right)$

\section{INTRODUCTION}

The energy supply for melting at glacier surfaces comes from several sources, net radiation and turbulent sensibleheat flux being the main ones. The relative magnitudes of the energy sources vary with situation but net radiation is generally the largest energy source on most glaciers (Paterson, 1969, p. 58-61), and results from the margin of the Greenland ice sheet (Braithwaite and Olesen, 1990a) agree with this pattern. However, if air temperatures rise, e.g. due to the enhanced greenhouse effect, more than half of the increased ablation will be caused by an increase in sensible-heat flux (Braithwaite and Olesen, 1990c). This statement refers to sensible-heat flux calculated for a neutral boundary layer, although rather stable aerodynamic conditions can be expected Grainger and Lister, 1966), and a temperature increase will involve increased stability. The present paper therefore re-examines the calculation of sensible-heat flux to assess the effect of aerodynamic stability and to see if previous conclusions about increased melting from Greenland need revision.

\section{BACKGROUND}

The vertical turbulent sensible-heat flux $H$ is expressed in flux-gradient form as:

$$
H=\rho c_{\mathrm{p}} K_{\mathrm{H}}(\mathrm{d} T / \mathrm{d} z-\Gamma)
$$


where $\rho$ is the density of air, $c_{\mathrm{p}}$ is the specific heat of air, $K_{\mathrm{H}}$ is the coefficient of turbulent diffusivity, $\mathrm{d} T / \mathrm{d} z$ is the vertical temperature gradient and $\Gamma$ is the adiabatic lapse rate. As the present paper only deals with the air layer close to the glacier surface (instrument height $2 \mathrm{~m}$ ) with large air-temperature gradients, $\Gamma$ is neglected compared with $\mathrm{d} T / \mathrm{d} z$. In the present paper, sensible-heat flux towards the glacier surface is taken as positive.

Despite the analogy of Equation (1) with the classic heat-conduction equation, the eddy diffusivity $K_{\mathrm{H}}$ is not a simple property of air. There is a substantial literature on how $K_{\mathrm{H}}$ varies with height over the surface and with the conditions of turbulence (Panofsky and Dutton, 1984; Garratt, 1992).

The turbulent shear stress $\tau$ at the glacier surface is the vertical flux of horizontal momentum:

$$
\tau=\rho K_{\mathrm{M}} \cdot \mathrm{d} u / \mathrm{d} z
$$

where $K_{\mathrm{M}}$ is the coefficient of eddy viscosity and $\mathrm{d} u / \mathrm{d} z$ is the vertical gradient of the horizontal wind speed. In laboratory studies of turbulence, the quantity $(\tau / \rho)^{0.5}$ is called the friction velocity $u_{*}$.

The essential point of the flux-gradient approach is to assume some kind of similarity, i.e. the Reynolds analogy, between $K_{\mathrm{H}}$ and $K_{\mathrm{M}}$ so that $K_{\mathrm{H}}$ can be estimated from the vertical wind profile immediately above the surface. Grainger and Lister (1966) discussed wind profiles that have been used in glaciological studies.

\section{LOGARITHMIC WIND PROFILE}

The simplest, and possibly most elegant, treatment of sensible-heat flux assumes that the wind speed increases as the natural logarithm of the height above the surface, i.e. the so-called logarithmic profile (Garratt, 1992, p. 45; Paterson, 1994, p. 60-66):

$$
u=\left(u_{*} / k\right) \cdot \ln \left(z / z_{0 \mathrm{U}}\right) \quad\left(z / z_{0 \mathrm{U}} \gg 1\right)
$$

where $u_{*}$ is the friction velocity, $k$ is von Karman's constant that appears in laboratory studies of turbulence, and $z_{0 \mathrm{U}}$ is the surface roughness, representing the very small height above the glacier surface where wind speed $u$ is zero. The logarithmic profile is based on the assumption that fluxes of momentum and heat are constant with height within the surface boundary layer (inertial sublayer) immediately over the glacier and that the eddy viscosity $K_{\mathrm{M}}$ is proportional to height $z$ :

$$
K_{\mathrm{M}}=k u_{*} z .
$$

This is only strictly valid for a neutral atmosphere but Grainger and Lister (1966) suggested that the logarithmic profile is applicable over a wide range of stability conditions and it has been used without modification by Föhn (1973), Martin (1975), Poggi (1977) and Hogg and others (1982). From the above, turbulent flux in a neutral atmosphere $H_{\mathrm{N}}$ is:

$$
H_{\mathrm{N}}=\frac{\rho c_{\mathrm{p}} k u_{*}\left(T-T_{0}\right)}{\left[\ln \left(z / z_{0 \mathrm{~T}}\right)\right]}
$$

where $z_{0 \mathrm{~T}}$ is the surface roughness for the temperature, i.e. the height where $T=T_{0}$ the surface temperature of the glacier. Throughout this paper, the glacier surface is assumed to be melting so that $T_{0}=0 \mathrm{deg}$. Elimination of the friction velocity between Equations (4) and (5) gives:

$$
H_{\mathrm{N}}=\rho c_{\mathrm{p}} A u T
$$

where $A$ is a dimensionless bulk-transfer coefficient. For neutral conditions, this is equal to $A_{\mathrm{N}}$ :

$$
A_{\mathrm{N}}=\frac{k^{2}}{\left[\ln \left(z / z_{0 \mathrm{~T}}\right) \cdot \ln \left(z / z_{0 \mathrm{U}}\right)\right]} .
$$

The wind speed $u$ and temperature $T$ are measured at the height $z$ (2 $\mathrm{m}$ for present purposes) and $A_{\mathrm{N}}$ is about $0.002-0.004$ for melting snow and ice surfaces (Paterson, 1994 , p. 65). The density of air $\rho$ in Equation (6) is estimated from the atmospheric pressure $b$ :

$$
\rho \approx \rho_{0}\left(b / b_{0}\right)
$$

where $\rho_{0}$ is the standard density of air and $b_{0}$ is the standard pressure, and $b$ is the mean atmospheric pressure for the particular site that can be estimated from its elevation above sea level using a standard atmosphere equation.

Equations (6)-(8) mean that sensible-heat flux can be calculated from wind and temperature data at one height $z$ if the bulk-transfer coefficient, which depends on the surface roughness lengths $z_{0 \mathrm{~T}}$ and $z_{0 \mathrm{U}}$, is known. The principle of calculating snow or ice ablation from simple meteorological data has been known for a long time (Angström, 1933; Sverdrup, 1935; Wilson, 1941) and the specific form in Equations (6) and (7) has been used in Greenland by Ambach (1986), Braithwaite and Olesen (1990a,c) and van de Wal and Russell (1994).

A wide range has been reported in the literature (Table 1) for surface roughness $z_{0 \mathrm{U}}$ over ice, mainly reflecting the effect of micro- and meso-scale topography on surface roughness (Munro, 1989), although Morris (1989) suggested that some of the larger roughness values may be caused by slope errors. This may account for the values in Table 1 for the GIMEX profile, in West Greenland, which are especially problematic because the roughness apparently increases from the ice-sheet margin (site 4) towards the interior (site 9), contrary to intuition.

Ambach (1986) suggested different roughness for wind speed, air temperature and humidity for ice and snow surfaces (Table 2) on the basis of energy-balance studies in both the ablation area (Ambach, 1963) and accumulation area (Ambach, 1977). Holmgren (1971) also found that the surface roughness is lower for snow than ice, but Munro (1989) and Bintanja and van den Broeke (1994) found the opposite, and some textbooks give snow a greater roughness than ice Oke, 1978; Panofsky and Dutton, 1984). There is general agreement that the surface roughness of snow increases with wind speed due to the effects of drifting (Garratt, 1992, p. 97-103), thus accounting for some large snow-roughness values, but drift is largely excluded if one is talking about melting snow and is absent for melting ice. Day-to-day variations of several orders of magnitude in surface roughness have 
Table 1. Surface roughness for wind speed over ice in units $10^{3} \mathrm{~m}$. Updated from Kuhn (1979) and Morris (1989)

\begin{tabular}{|c|c|c|}
\hline $\begin{array}{l}\text { Hoinkes and Untersteiner } \\
(1952)\end{array}$ & Vernagtferner & 1.5 \\
\hline Hoinkes (1953) & Hornkees & 1.7 \\
\hline Untersteiner (1957) & Chogo Lungma & 2 \\
\hline Skeib (1962) & Zentralnyy Tuyuksu & 1.1 \\
\hline Ambach (1963) & EGIG Camp IV & 1.8 \\
\hline Keeler (1964) & Sverdrup Glacier & 4.4 \\
\hline Havens and others (1965) & White Glacier & 6.7 \\
\hline \multirow{3}{*}{ Grainger and Lister (1966) } & Storglaciären & 0.1 \\
\hline & Britannia Gletscher & 7 \\
\hline & Britannia Gletscher & 5 \\
\hline $\begin{array}{l}\text { Streten and Wendler } \\
(1968)\end{array}$ & Worthington Glacier & or 1.8 \\
\hline Holmgren (1971) & $\begin{array}{l}\text { Devon Island } \\
\text { Ice Cap }\end{array}$ & 1.3 \\
\hline $\begin{array}{l}\text { Wendler and Weller } \\
(1974)\end{array}$ & $\begin{array}{l}\text { McCall Glacier, } \\
\text { Alaska }\end{array}$ & 2.4 \\
\hline Martin (1975) & $\begin{array}{l}\text { Glaciar Saint- } \\
\text { Sorlin }\end{array}$ & $5.5-6.9$ \\
\hline Poggi (1977) & $\begin{array}{l}\text { Ampère Glaciar, } \\
\text { Kerguelen }\end{array}$ & 1 \\
\hline d others (1982) & Hodges Glacier & 1.3 \\
\hline Hay and Fitzharris (1988) & Ivory Glacier & 14 \\
\hline Munro (1989) & Peyto Glacier & $0.7-2.4$ \\
\hline Munro (1990) & Peyto Glacier & 2.5 \\
\hline $\begin{array}{l}\text { Duynkerke and } \\
\text { van den Broeck (1994) }\end{array}$ & $\begin{array}{l}\text { GIMEX - site } 4 \\
\text { GIMEX - site } 5 \\
\text { GIMEX - site } 6 \\
\text { GIMEX - site } 9\end{array}$ & $\begin{array}{c}40 \\
4 \\
0.8 \\
8\end{array}$ \\
\hline $\begin{array}{l}\text { Van de Wal and Russell } \\
\text { (1994) }\end{array}$ & GIMEX - model & 1 \\
\hline
\end{tabular}

also been reported for melting snow (Plüss and Mazzoni, 1994), presumably reflecting real variations as well as measurement errors, which must be considerable.

Less is known about the surface roughness $z_{0 T}$ for temperature but Sverdrup (1935), Holmgren (1971) and Ambach (1986) have agreed that it is about two orders of magnitude smaller than $z_{0 \mathrm{U}}$. Although some authors assume the roughness is the same for both profiles, there is no reason, in principle, why they should be the same because the transfer processes are different close to the surface, e.g. there is no flux of momentum through the

Table 2. Surface roughness for wind speed, air temperature and humidity profiles according to Ambach (1986). Units are metres

\begin{tabular}{lll}
\hline & Snow & Ice \\
\hline Momentum & $1 \times 10^{-4}$ & $2 \times 10^{-3}$ \\
Temperature & $6 \times 10^{-6}$ & $6 \times 10^{-6}$ \\
Vapour pressure & $6 \times 10^{-6}$ & $6 \times 10^{-6}$
\end{tabular}

interficial sub-layer (of thickness $z_{0 \mathrm{U}}$ ) while heat transfer is by molecular diffusion. This prompted Andreas (1987) to express the ratio $z_{0 \mathrm{~T}} / z_{0 \mathrm{U}}$ as a function of the roughness Reynolds number, and with the appropriate values Andreas's model predicts that $z_{0 \mathrm{~T}}$ should be $10-100$ times smaller than $z_{0 \mathrm{U}}$, in rough agreement with Ambach (1986) but Munro (1989) and King and Anderson (1994) found to the contrary.

In view of the above disagreements, to simplify the treatment, and to anticipate the result that Ambach's surface roughness lengths need not apply to the icemargin area, even if they apply to the upper ablation area, it is convenient to follow Morris and Harding (1991) in assuming that $z_{0 \mathrm{U}}=z_{0 \mathrm{~T}}=z_{0}$, the effective roughness for sensible-heat flux such that:

$$
A_{\mathrm{N}}=\frac{k^{2}}{\left[\ln \left(z / z_{0}\right)\right]^{2}} .
$$

For Equation (9) to give the same numerical value for $A_{\mathrm{N}}$ as Equation (7) with the ice roughness from Ambach (1986), i.e. $z_{0 \mathrm{U}}=2 \times 10^{-3} \mathrm{~m}$ and $z_{0 \mathrm{~T}}=6 \times 10^{-6} \mathrm{~m}$ for ice, an effective value of $z_{0}=1.7 \times 10^{4} \mathrm{~m}$ is assumed.

The sensible heat flux (Fig. 1) is calculated according to Equations (6) and (9) for different values of temperature and wind speed. The atmospheric pressure is $90 \mathrm{kPa}$, corresponding to an elevation of about $1000 \mathrm{~m}$ a.s.l., which is typical of the middle of the ablation area in West Greenland. The range of temperature and wind is chosen to be typical of those prevailing at Nordbogletscher and Qamanârssûp sermia (West Greenland) during the summer months June-August. The sensibleheat flux in the model is linear with respect to increasing temperature. This is true as long as the glacier surface is melting but surface temperatures need not remain at the melting point even with air temperatures above 0 deg (Kuhn, 1987), so there might be greater sensible-heat flux to the (non-melting) glacier surface at the lower air temperatures.

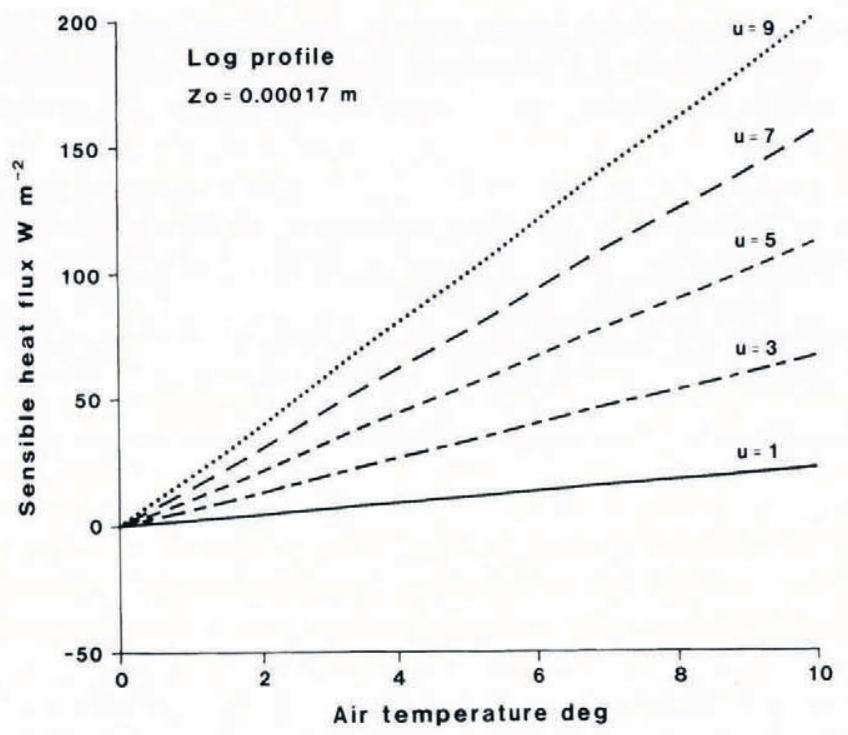

Fig. 1. Sensible-heal flux for the logarithmic wind profile with wind speeds $1-9 \mathrm{~m} \mathrm{~s}^{-1}$. Temperature and wind at $2 \mathrm{~m}$ above melting glacier surface. 
It is now necessary to consider the effect of stability on the sensible-heat flux that has been neglected up to this point.

\section{AERODYNAMIC STABILITY OVER MELTING ICE}

When an air parcel is displaced upwards by turbulence from its usual height, it cools at the adiabatic lapse rate $\Gamma$. The air parcel experiences negative or positive buoyancy forces according to whether it is now warmer (less dense) or cooler (more dense) than its new surroundings and the buoyancy forces tend to amplify or inhibit the further movement of the air parcel. In the case of a melting glacier in the summer, the air temperature generally increases in the first few metres over the surface and buoyancy forces inhibit turbulence (Grainger and Lister, 1966). The surface layer is said to be aerodynamically stable. The derivation of the sensible-heat flux for a logarithmic wind profile neglects the effect of stability and the flux in Figure 1 may therefore be overestimated.

The stability, or otherwise, of the surface layer is described by the bulk Richardson number $(\mathrm{Ri})$ which relates the relative effects of buoyancy to mechanical forces (Oke, 1978). The bulk Richardson number at height $z$ over a melting surface $\left(T_{0}=0 \mathrm{deg}\right)$ is:

$$
\left.\mathrm{Ri}=(g T z) / T_{\mathrm{K}} u^{2}\right)
$$

where $g$ is the acceleration of gravity and $T_{\mathrm{K}}$ is the air temperature on the absolute scale $(\mathrm{K}) . \mathrm{Ri}$ is positive in a stable atmosphere.

The variations of Richardson number with wind speed $u$ and temperature $T$ (both at $2 \mathrm{~m}$ ) are shown in Figure 2 where the glacier surface is once again assumed to be melting. The boundary between "fully forced convection" (neutral) and "damped forced convection" (stable) is $\mathrm{Ri}=0.01$ (Oke, 1978) and the critical value of $\mathrm{Ri}$ for the transition to "no convection" is about +0.2 (Webb, 1970). The variations of Ri (Fig. 2) show that turbulent

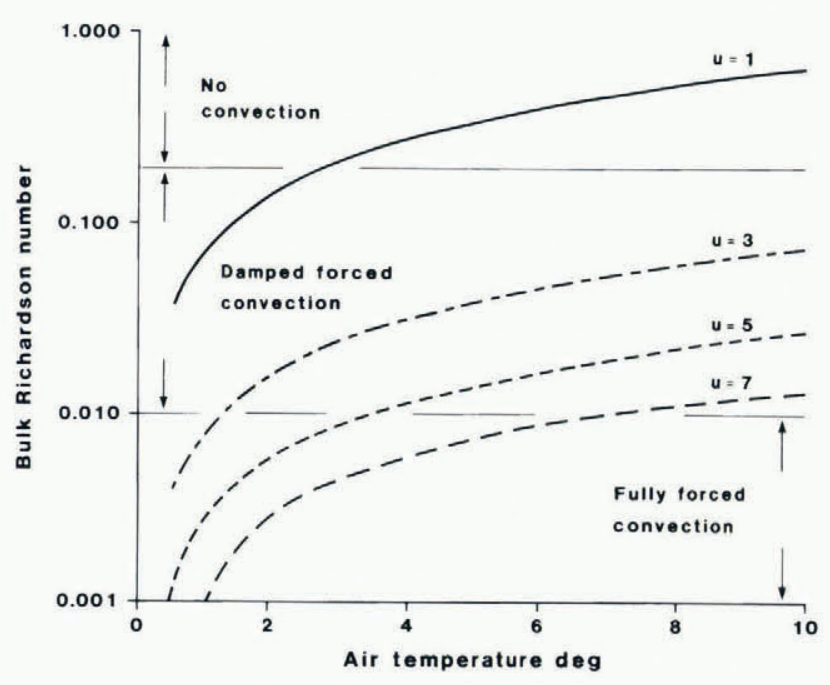

Fig. 2. Bulk Richardson number at $2 m$ above a melting ice surface with wind speeds of $1-9 \mathrm{~m} \mathrm{~s}^{-1}$. conditions may be close to neutral for higher wind speeds, i.e. $7 \mathrm{~m} \mathrm{~s}^{-1}$ or more, up to quite high temperatures. Stable conditions may be expected for medium wind speeds, $3-$ $5 \mathrm{~ms}^{-1}$, over most of the temperature range while turbulence essentially disappears for low wind speed, $1 \mathrm{~ms}^{-1}$ or less.

Some authors correct the sensible-heat flux over melting snow or ice for effects of stability, either by simple functions of the bulk Richardson number or by using the Monin-Obukhov stability function $\phi$ (Panofsky and Dutton, 1984; Garratt, 1992) that is related to Ri. Snowmelt studies by Price and Dunne (1976) and Braun (1985) used:

$$
H_{\mathrm{S}} / H_{\mathrm{N}}=1 /(1+10 \mathrm{Ri})
$$

where $H_{\mathrm{S}}$ is the sensible-heat flux in stable conditions and $H_{\mathrm{N}}$ is for neutral conditions. The correction factor (Fig. 3) shows only small variations up to quite high temperatures for higher wind speeds but is small for low wind speeds where the Richardson number is high. Another

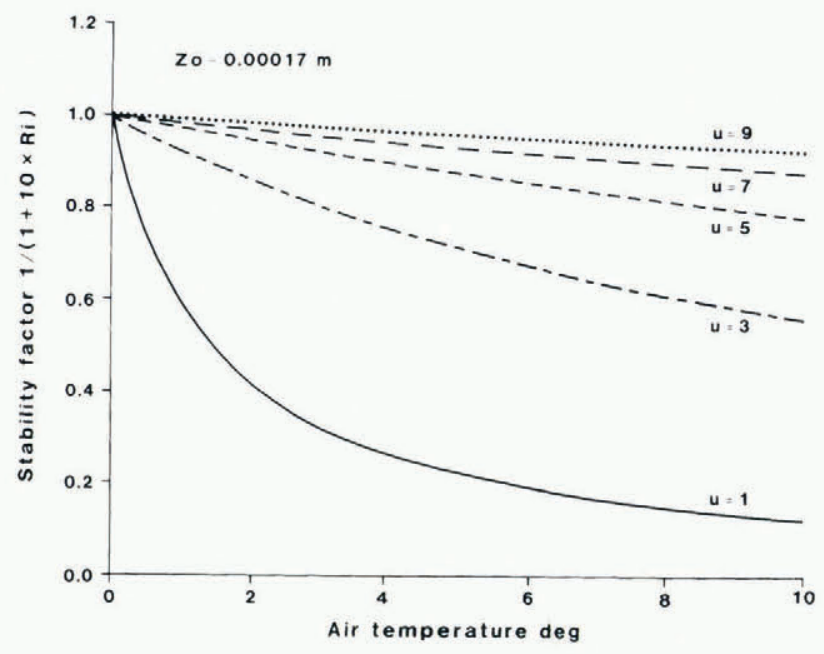

Fig. 3. Stability correction factor $1 /(1+10 R i)^{2}$ at $2 \mathrm{~m}$ above a melting glacier.

correction factor has been used for snowmelt by Weisman (1977) and Moore (1983), and on a glacier by Hay and Fitzharris (1988):

$$
\begin{array}{rlrl}
H_{\mathrm{S}} / H_{\mathrm{N}} & =(1-5 \mathrm{Ri})^{2} & 0.2>\mathrm{Ri}>0.01 \\
=0 & \mathrm{Ri}>0.2 .
\end{array}
$$

This correction factor (Fig. 4) is essentially the same as the previous one (Fig. 3) for higher wind speeds $(5-9 \mathrm{~m}$ $\left.\mathrm{s}^{-1}\right)$ but drops to zero much more rapidly for lower wind speeds $\left(1 \mathrm{~m} \mathrm{~s}^{-1}\right)$, i.e. it shows a stronger cut-off of sensibleheat flux due to stability.

The sensible-heat flux using the logarithmic wind profile may be overestimated under the very stable conditions encountered at low wind speeds over a melting glacier. On the other hand, stability effects are fairly small at the high wind speeds that are common on the Greenland ice sheet. As an alternative to using the correction factors in Figures 3 and 4, the use of a different wind profile is now considered. 


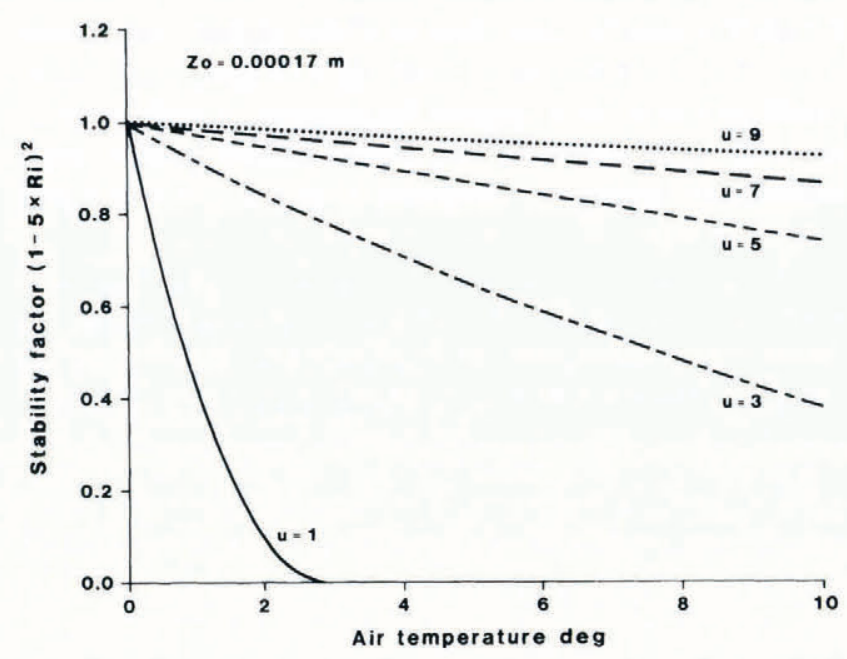

Fig. 4. Stability correction factor $(1-5 R i)^{2}$ at $2 \mathrm{~m}$ above a melting glacier.

\section{LOG-LINEAR WIND PROFILE}

For the $\log$ linear profile, based on the work of Monin and Obukhov (Garratt, 1992, p. 52-54), the wind at height $z$ is given by:

$$
u=\left(u_{*} / k\right)\left[\ln \left(z / z_{0 \mathrm{U}}\right)+\alpha(z / L)\right]
$$

where $\alpha$ is an experimental parameter and $L$ is the scale height of Obukhov (1971):

$$
L=\frac{\rho c_{\mathrm{p}} u_{*}^{3} T_{\mathrm{K}}}{k g H} .
$$

Some authors, e.g. Kraus (1973), have included an extra term in the denominator of $L$ to incorporate the effects of vapour stratification on buoyancy but Obukhov's original formulation is used here. By analogy with Equation (9), and assuming again the same parameters for wind and temperature profiles, the bulk-transfer coefficient $A_{\mathrm{S}}$ for stable conditions is:

$$
A_{\mathrm{S}}=\frac{k^{2}}{\left[\ln \left(z / z_{0}\right)+\alpha(z / L)\right]^{2}} .
$$

There is an extensive literature on $\alpha$, summarized by Garratt (1992, p. 289) but this study follows Munro (1989) in assuming that $\alpha=5$ for both wind and temperature profiles in stable conditions as proposed by Dyer (1974).

The log-linear profile has been used over glaciers by Grainger and Lister (1966), Kraus (1973, 1975), Casiniére (1974), Derikx (1975), Munro and Davies (1977), and Munro $(1989,1990)$, and in Greenland by Duynkerke and van den Broeke (1994). One apparent difficulty is that the Obukhov length $L$ is needed to calculate the sensible-heat flux while one needs to know the sensibleheat flux to calculate $L$. Munro (1989) overcame this vicious circle by an iterative procedure whereby $H$ is first calculated for $z / L=0$ (neutral case), then a new $L$ is calculated from $H$ and an updated $H$ is calculated from the new $L$, the whole procedure being repeated for a number of iterations. The present study agrees with Munro (1989) that the iterations quickly converge and the calculation of sensible-heat flux for the $\log$-linear profile is therefore hardly more time-consuming than for the logarithmic profile.

Sensible-heat fluxes for the log-linear profile (Fig. 5) are generally similar to those for the logarithmic profile (Fig. 1) except that (1) sensible-heat flux is no longer exactly linear with temperature and (2) fluxes are lower for the same wind and temperature conditions as before, reflecting the inhibition of turbulence by stability. In particular, sensible-heat flux becomes zero at very low winds speeds $\left(1 \mathrm{~m} \mathrm{~s}^{-1}\right)$, although there is a non-zero heat flux (too small to be seen in Figure 5) at both low wind speeds and low temperatures (1-2 deg).

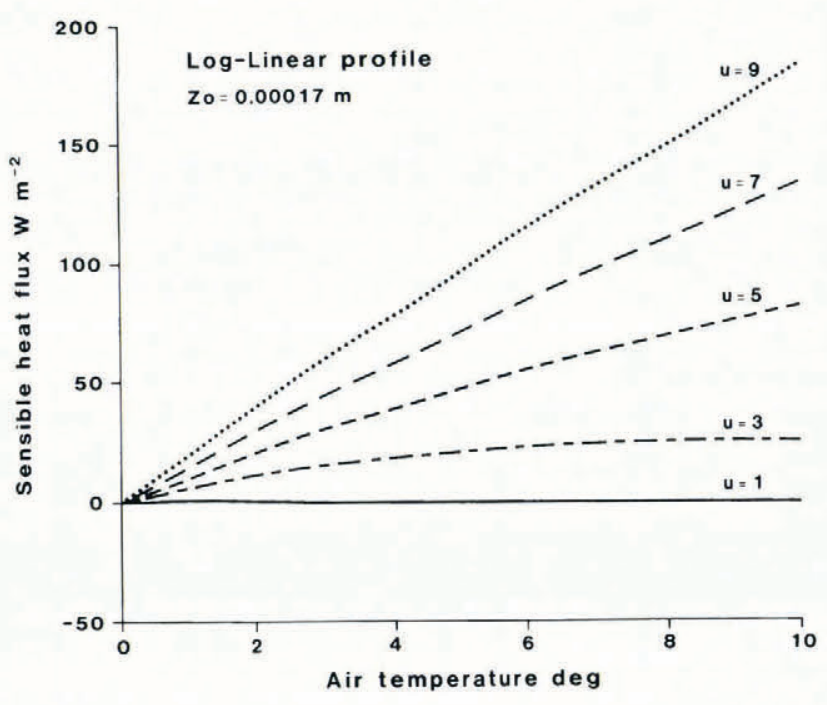

Fig. 5. Sensible-heat flux for the $\log$-linear wind profile with wind speeds $1-9 \mathrm{~m} \mathrm{~s}^{-1}$. Temperature and wind at $2 \mathrm{~m}$ above melting glacier surface.

\section{RELATIVE EFFECTS OF STABILITY AND ROUGHNESS}

Braithwaite and Olesen (1990a) calculated the energy balance at two sites in West Greenland with a model that uses the logarithmic wind profile for the sensible-heat flux. This seemed a reasonable thing to do at the time because (1) Grainger and Lister (1966) implied that the logarithmic profile is valid over a wide stability range, and (2) ablation calculated for neutral conditions was found to fit observed ablation rather well on the average. However, the calculation of the sensible-heat flux is now repeated using the $\log$-linear profile, with all other data and assumptions as before. For convenience, only cases with $T \geq 0 \mathrm{deg}$ are considered (386 d at Nordbogletscher and $480 \mathrm{~d}$ at Qamanârssûp sermia) so a frozen glacier surface is largely excluded.

The mean sensible-heat flux with the $\log$-linear profile is respectively 74 and $84 \%$ of the corresponding values for the logarithmic profile (Table 3). In round figures, stability reduces sensible-heat flux by about one-fifth compared with neutral conditions, with a smaller reduction at Qamanârssûp sermia (mean air temper- 
Table 3. Mean sensible-heat fluxes for two sites in West Greenland. Cases with air temperalure above 0 deg

Nordbogletscher

Stake
Elevation (m a.s.l.)
Latitude $(\mathrm{N})$
Number of days
Mean air temperature $(\mathrm{deg})$
Mean wind speed $\left(\mathrm{m} \mathrm{s}^{-1}\right)$
Ablation flux $\left(\mathrm{W} \mathrm{m}^{-2}\right)$
Sensible-heat flux $\left(\mathrm{W} \mathrm{m}^{-2}\right)$
$\quad$ Log linear
$\quad$ Log profile
Ratio

53

880

$61^{\circ} 28^{\prime}$

386

4.1

3.3

119.1

25.9

34.9

0.74
Qamanârssûp
751
790
$64^{\circ} 28^{\prime}$
480
5.4
5.0
170.7
54.4
65.0
0.84

ature $5.4 \mathrm{deg}$ and mean wind speed $5.0 \mathrm{~m} \mathrm{~s}^{-1}$ both at $2 \mathrm{~m}$ above the glacier surface) than at Nordbogletscher (4.1 deg and $3.3 \mathrm{~m} \mathrm{~s}^{-1}$ ), because stability is weaker due to the higher mean wind speed.

The reduction in calculated sensible-heat flux by stability appears to imply that the energy-balance model of Braithwaite and Olesen (1990a) overestimates ablation by the same amount that sensible-heat flux is overestimated, i.e. equivalent to overestimating mean ablation by 6 and $8 \%$ at the two sites. However, such an overestimation is excluded because there was on average good agreement between measured and calculated ablation at the two sites Braithwaite and Olesen, 1990a). There must therefore be another source of error that more-or-less compensates for the effect of stability. The most likely candidate is the choice of roughness. The preceding calculations all use $z_{0}=0.00017 \mathrm{~m}$, which actually refers to the relatively smooth ice studied by Ambach (1963) in the upper ablation area. The roughness of ice in the outer ablation area, as at Nordbogletscher and Qamanârssûp sermia, could well be an order-of-magnitude greater.

The curves in Figure 6 show that a ten-fold increase in surface roughness $z_{0}$ has a larger effect on sensible-heat

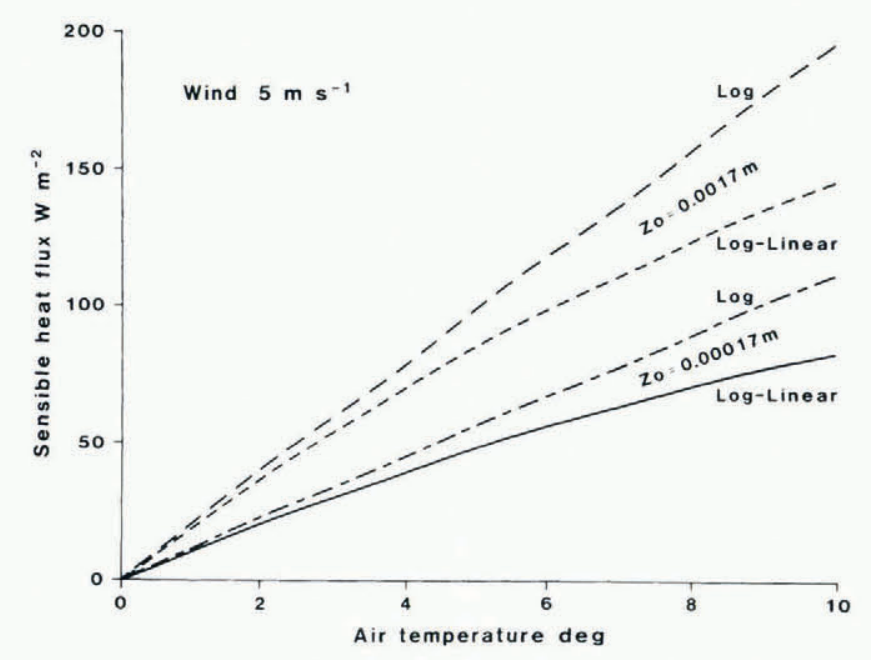

Fig. 6. Sensible-heat fluxes for different surface roughness and different wind profiles. flux than the effect of stability as expressed by the difference between logarithmic and $\log$-linear profiles (wind speed $5 \mathrm{~ms}^{-1}$ at $2 \mathrm{~m}$ for all cases).

\section{NEGLECT OF WIND VARIATIONS}

The logical extension to calculating sensible-heat flux from temperature and wind-speed data at one height is to use temperature data alone. This is the basis of a method whereby wind speed is "lumped" into a bulk heat-transfer coefficient (Kuhn, 1979; Moore, 1983; Moore and Owens, 1984: Escher-Vetter, 1985; Hay and Fitzharris, 1988). Such a simplification is attractive because it is often difficult to get data for wind speed in glacier areas, and especially over the whole Greenland ice sheet, while temperature data can be easily extrapolated from a distant station. The definition of the heat-transfer coefficient $\beta$ is:

$$
\bar{H}=\beta \bar{T}
$$

where $\bar{H}$ is the mean sensible-heat flux over many days and $\bar{T}$ is the mean temperature over the same period. By comparison with Equations (6), (8) and (15), it is obvious that $\beta$ must depend implicitly upon mean wind speed, roughness, measurement height and the density of air, and thereby elevation above sea level. The transfer coefficient is at most a parameter (quantity constant in the case considered but varying in different cases; The Concise Oxford Dictionary, sixth edition) rather than a strict constant. For the logarithmic wind profile (Fig. 1), sensible-heat flux is certainly proportional to temperature for a constant wind speed and is nearly proportional for most of the log-linear profile (Fig. 5).

For varying wind speed, $\beta$ also depends upon the correlation between wind speed and temperature, which is positive at both sites due to an association of high wind speeds with high temperatures under Föhn-type events (correlation coefficients of +0.41 and +0.42 , respectively, for Nordbogletscher and Qamanârssûp sermia). As mean wind speed is implicit in $\beta$, a correlation between transfer coefficients and mean wind speeds in different situations may be expected (Kuhn, 1979), although Funk 
(1985, p. 165-75) did not find notably high correlations (the expected correlations were probably obscured by other effects).

One way of isolating the temperature sensitivity of sensible-heat flux is by simple least-squares regression of the calculated sensible-heat flux on air temperature, i.e. a kind of re-sampling procedure. The resulting regression equation represents the flux -temperature relation for the average wind conditions prevailing in the data set. The regression equation for the $\log$ linear profile at Nordbogletscher (days with $T \geq 0 \mathrm{deg}$ ) is:

$$
H_{\mathrm{S}}=-15.2+9.9 T \quad R=0.64 \quad N=386
$$

where $R$ is the correlation coefficient and $N$ is the sample size in days. The corresponding equation for the logarithmic profile at Nordbogletscher is:

$$
H_{\mathrm{N}}=-13.4+14.5 T \quad R=0.83 \quad \mathrm{~N}=386 .
$$

The equations for Qamanârssûp sermia (days with $T \geq 0$ deg) are:

$$
H_{\mathrm{S}}=-18.8+13.5 T \quad R=0.73 \quad N=480
$$

and

$$
H_{\mathrm{N}}=-21.5+16.0 T \quad R=0.82 \quad N=480 .
$$

The negative intercepts in all four equations have no deep physical significance and probably arise because temperature and wind speed are positively correlated, increasing the slope of the regression line and forcing the intercept below zero. If there were no correlation between wind speed and temperature, the intercept would be essentially zero and the slopes would be less than here.

The slopes in the regression equations have the nature of heat-transfer coefficients. The effect of stability is to reduce these coefficients, by 32 and $16 \%$, respectively, for the present cases, or by about one-quarter in round figures, although, as said previously, this could be offset again by using larger roughness to recalculate the sensible-heat fluxes.
The heat-transfer coefficients for the present cases are compared with others from the literature (Table 4), showing a fairly wide range, which presumably reflects variations in wind specd and roughness. The heat-transfer coefficient of Kuhn (1979) refers to an alpine glacier and is rather larger than the Greenland values in Table 4 despite its greater altitude. Presumably, the surface roughness is large and more than offsets the effect of lower atmospheric pressure (as discussed in the next section).

The three transfer coefficients in the middle of Table 4, which have been used for modelling (Oerlemans and Hoogendoorn, 1989; Oerlemans, 1991, 1992), refer to assumed values at the glacier snouts that decrease with altitude but no reasons for choosing different values for the different models are given. The correct choice of transfer coefficient is important for assessing the sea-level rise due to increased melting of mountain glaciers, which Oerlemans and Fortuin (1992) said is less than previously estimated.

The most serious objection to the widespread use of heat-transfer coefficients is the problem of choosing a suitable value to take account of wind conditions in Greenland, i.e. mean wind speed and surface roughness. Recent research on the dynamics of the boundary layer over the Greenland ice sheet (Oerlemans and Vugts, 1993) may help us to guess wind-speed distributions where observations are lacking. For example, Meesters and others (1994) suggested that wind speeds are higher over the upper ablation area than over the tundra and glacier margin.

\section{GEOGRAPHICAL VARIATIONS OF SENSIBLE- HEAT FLUX}

The dependence of sensible-heat flux on the density of air $\rho$ also implies a geographical variation in the size of sensible-heat fluxes, because glaciers in different regions are located at different altitudes. This point is illustrated (Fig. 7) by calculations for different values of atmospheric pressure: $90 \mathrm{kPa}$ (typical of the mid-ablation area of the Greenland ice sheet), $70 \mathrm{kPa}$ (Alps and Rockies) and $50 \mathrm{kPa}$ (Andes and Himalaya).

Table 4. Heat-transfer coefficients for turbulent heat flux according to various authors

$\mathrm{W} \mathrm{m}^{-2} \mathrm{deg}^{-1} \quad \mathrm{mmd}^{-1} / \mathrm{deg}^{-1} \quad$ References

$\begin{array}{lccl}\text { Hintereisferner } & 19.4 & 5.0 & \text { Kuhn (1979) } \\ \text { White Glacier } & 14.0-18.2 & 3.6-4.7 & \text { Braithwaite (1981) } \\ \text { Sverdrup Glacier } & 14.7 & 3.8 & \text { Braithwaite (1981) } \\ \text { Rhonegletscher } & 10.5-17.8 & 2.7-4.6 & \text { Funk (1985) } \\ \text { Alpine model } & 10.0 & 2.6 & \text { Oerlemans and Hoogendoorn (1989) } \\ \text { Greenland model } & 15.0 & 3.9 & \text { Oerlemans (1991) } \\ \text { Norwegian model } & 7.0 & 1.8 & \text { Oerlemans (1992) } \\ \text { Nordbogletscher } & 9.9 & 2.6 & \text { Log-linear profile } \\ & 14.5 & 3.7 & \text { Logarithmic profile } \\ \text { Qamanârssûp sermia }^{*} & 13.5 & 3.5 & \text { Log-linear profile } \\ & 16.0 & 4.1 & \text { Logarithmic profile }\end{array}$

\footnotetext{
"Surface roughness $0.00017 \mathrm{~m}$.
} 


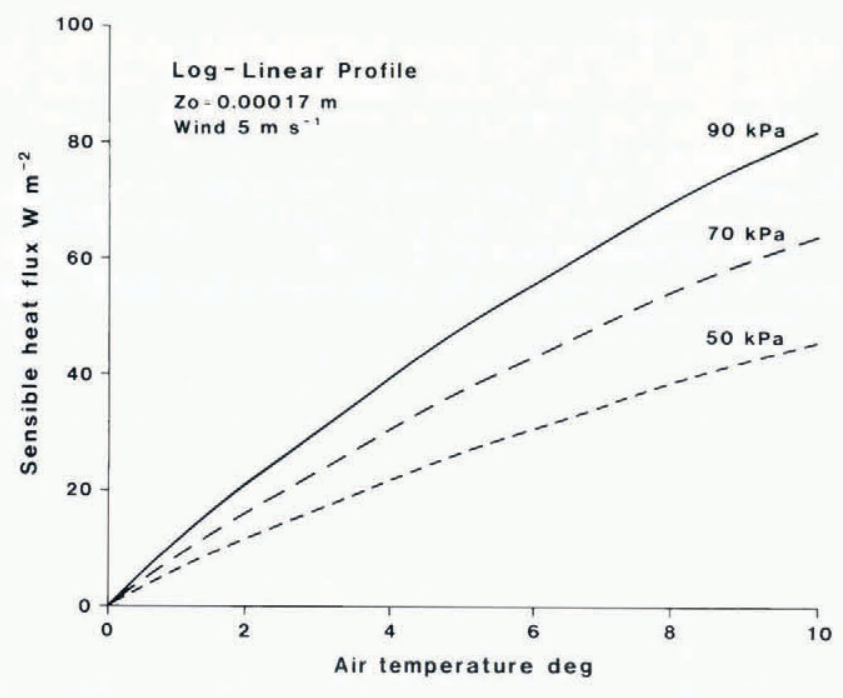

Fig. 7. Effect of atmospheric pressure variations on turbulent sensible-heat flux.

All things being equal, the heat flux in the Andes and Himalaya should only be about one-half of that in Greenland for the same temperature and wind speed, although variations within Greenland are relatively small, because of the restricted range of ablation-area altitudes. There are probably also differences in surface roughness for different glacier regions, e.g. due to different frequencies of surface debris, weathering crust and surface features like hummocks, suncups and penitents. For example, in Greenland, the ice surface is more bumpy close to the margin of the ice sheet than close to the equilibrium line. Different temperature sensitivity can therefore be expected for sensible-heat flux in different glacier regions and may contribute to inter-regional variations in positive degree-day factors Braithwaite, 1995), although these have not yet been clearly identified.

\section{DISCUSSION}

The bulk-exchange coefficient $A_{\mathrm{S}}$ given in Equation (15) is only approximately correct. A more exact formula is:

$$
A_{\mathrm{S}}=\frac{k^{2}}{\left[\ln \left(z / z_{0 \mathrm{U}}\right)+\alpha_{\mathrm{U}}(z / L)\right]\left[\ln \left(z / z_{0 \mathrm{~T}}\right)+\alpha_{\mathrm{T}}(z / L)\right]}
$$

where different roughness and $\alpha$ parameters are used for wind and temperature profiles. The roughness lengths determine the magnitude of sensible heat for neutral conditions and the $\alpha$ parameters determine the shape of the stability function, i.e. the way in which sensible-heat flux is reduced with increasing stability. More research is needed to find the most appropriate values of these parameters to use in any particular situation. A minimum requirement would be to take account of differences between ice and snow surfaces, as well as accounting for broad differences in surface types.

It is easy to criticize the use of the effective surface roughness $z_{0}$ in the present paper, because there is evidence, both empirical and theoretical, that surface roughness for wind and temperature profiles is generally different. However, it is not immediately clear what values should be used. For example, most evidence suggests that $z_{0 \mathrm{~T}}$ is much less than $z_{0 \mathrm{U}}$ but some authors have suggested the contrary. The effective roughness $z_{0}$ must lie between $z_{0 \mathrm{U}}$ and $z_{0 \mathrm{~T}}$ and, as realistic values of sensible-heat flux can be calculated with $z_{0}$ values that are lower than $z_{0 \mathrm{U}}$ values from the literature, the present study implies that $z_{0 \mathrm{~T}}$ is indeed much less than $z_{0 \mathrm{U}}$.

The important issue is the precise form of stability function, or of $\alpha$ values, to be used in large-scale hydrological and climatological models for climatechange experiments. The assumption of the same $\alpha$ for wind and temperature profiles under stable conditions $(\alpha=5)$ is taken from Dyer (1974) but other values have been proposed (Garratt, 1992, p. 289). A particularly respected recent study outside Greenland by Högström (1988) suggests higher $\alpha$ values of 6.0 and 7.8, respectively, for wind and temperature profiles.

For a whole generation, the best information on boundary-layer conditions in Greenland has been from Ambach (1963, 1977), Lister and Taylor (1961) and Grainger and Lister (1966) but no discussion on $\alpha$ has been possible. However, in the early 1990s, extensive new data were collected in West Greenland by Dutch and Swiss expeditions Oerlemans and Vugts, 1993; Ohmura and others, 1994), including the first direct measurements in Greenland of turbulent fluxes using eddy-correlation instruments. Preliminary results from these studies Forrer and Rotach, 1994; Henneken, 1994; Ohmura and others, 1994) indicate $\alpha$ values even larger than those proposed by Högström (1988). The stability factor (1$5 \mathrm{Ri})^{2}$ (Fig. 4) agrees closely with the $\log$ linear profile $(\alpha$ $=5$ ) and a larger $\alpha$ value implies an even sharper cut-off of sensible-heat flux with increasing stability.

The effect of stability on sensible-heat flux over the Greenland ice sheet is well illustrated by figure 7 in Ohmura and others (1994), which compares field measurements with curves from Webb (1970) (essentially the same as the Dyer (1974) model used here) and Högström (1988) as well as from the ECHAM 3 global climate model (GCM). The field measurements show a stronger stability effect than either the Webb or Högström models but it is particularly disturbing that the GCM shows a much weaker stability effect, implying serious overestimation of sensible-heat flux by this GCM. This must be remedied before the GCM is used to calculate the impact of climate changes on the Greenland ice sheet.

\section{CONCLUSIONS}

Aerodynamic stability reduces sensible-heat flux over a melting ice surface compared to that predicted for a stable boundary layer. The stability effect is fairly small for the high wind speeds that are common over the Greenland ice sheet but it is very large at low wind speeds.

The uncertainty in surface roughness probably causes greater error in sensible-heat-flux calculations than the neglect of stability. However, the $\log$-linear wind profile is only slightly more difficult to use than the logarithmic profile and should be used for future calculations of sensible-heat flux, because it is more realistic.

Lack of wind-speed data over the Greenland ice sheet 
is a problem for calculating sensible-heat flux. The use of a bulk heat-transfer coefficient avoids the need for wind data but there is still an uncertainty about the choice of the coefficient itself.

Sensible-heat flux depends on air pressure and this implies a geographical variation of heat flux because glaciers in different regions are located at different altitudes.

It cannot be concluded definitely that an earlier estimate of increased melting from the Greenland ice sheet (Braithwaite and Olesen, 1990a) is too high, because calculated ablation in that study agreed fairly well with observed ablation. The effect of neglecting stability was probably offset by underestimation of the surface roughness for sensible-heat flux.

\section{ACKNOWLEDGEMENTS}

This paper is published by permission of the Geological Survey of Greenland (GGU) and is a contribution under contract EV5V-CT91-0051 from the European Community, co-ordinated by the Climate Research Unit, University of East Anglia, England. The paper was inspired by discussions in November 1993 when the author was an academic guest of Professor A. Ohmura, Geographische Institut, Eidgenössiche Technische Hochschule, under ETH grant No. 0-04-509-93, although 1 month in such a stimulating environment was too short to remedy a lifetime of ignorance about atmospheric turbulence. The drawings were prepared by G.F. Hansen (GGU).

\section{REFERENCES}

Ambach, W. 1963. Untersuchungen zum Energieumsatz in der Ablationszone des grönländischen Inlandeises (Camp IV-EGIG, $69^{\circ} 40^{\prime} 05^{\prime \prime}$ N, $49^{\circ} 37^{\prime} 58^{\prime \prime}$ W). Medd. Gronl., 174(4).

Ambach, W. 1977. Untersuchungen zum Energieumsatz in der Akkumulationszone des grönländischen Inlandeises. Medd. Gronl., $187(7)$.

Ambach, W. 1986. Nomographs for the determination of meltwater from snow- and ice surfaces. Berichte des NaturwissenschaftlichMedizinischen Vereins in Innsbruck, 73, 7-15.

Andreas, E. L. 1987. A theory for the scale roughness and the scalar transfer coefficients over snow and sea ice. Boundary-Layer Meteorol., $38(1-2), 159-184$.

Angström, A. 1933. On the dependence of ablation on air temperature, radiation and wind. Geogr. Ann., 15(4), 264271.

Bintanja, R. and M. R. van den Broeke. 1994. Local climate, circulation and surface-energy balance of an Antarctic blue-ice area. Ann. Glaciol., 20, 160-168.

Braithwaite, R.J. 1981. On glacier energy balance, ablation, and air temperature. J. Glaciol., 27 (97), 381-391.

Braithwaite, R.J. 1995. Positive degree-day factors for ablation on the Greenland ice sheet studied by energy-balance modelling. 7. Glaciol., 41(137), 153-160.

Braithwaite, R.J. and O.B. Olesen. 1990a. A simple energy-balance model to calculate ice ablation at the margin of the Greenland ice sheet. 7. Glaciol., 36(123), 222-228.

Braithwaite, R.J. and O.B. Olesen. 1990b. Increased ablation at the margin of the Greenland ice sheet under a greenhouse-effect climate. Ann. Glaciol., 14, 20-22.

Braithwaite, R. J. and O.B. Olesen. 1990c. Response of the energy balance on the margin of the Greenland ice sheet to temperature changes. J. Glaciol., 36(123), 217-221.

Braun, L. N. 1985. Simulation of snowmelt-runoff in lowland and lower Alpine regions of Switzerland. Zürcher Geogr. Schr. 21.

Casinière, A. C. de la. 1974. Heat exchange over a melting snow surface. f. Glaciol., $13(67), 55-72$.

Derikx, L. 1975. The heat balance and associated runoff from an experimental site on a glacier tongue. International Association of Hydrological Sciences Publication 104 (Symposium at Moscow 1971 Snow and Ice), 59-69.

Duynkerke, P. G. and R. van den Broeke. 1994. Surface energy balance and katabatic flow over glacier and tundra during GIMEX-91. Global and Planetary Change, 9(1-2), 17-28.

Dyer, A.J. 1974. A review of flux-profile relationships. Boundary-Layer Meteorol., 7, 363-372.

Escher-Vetter, H. 1985. Energy balance calculations for the ablation period 1982 at Vernagtferner, Oetztal Alps. Ann. Glaciol., 6, 158-160.

Föhn, P. M. B. 1973. Short-term snow melt and ablation derived from heat- and mass-balance measurements. f. Glaciol., 12 (65), 275-289.

Forrer, J. and M. Rotach. 1994. Comparison between measured and calculated turbulent fluxes. Gronlands Geologiske Undersogelse, Ser. Open File, $94(13), 36-39$.

Funk, M. 1985. Räumliche Verteilung der Massenbilanz auf dem Rhonegletscher und ihre Beziehung zu Klimaelementen. Zürcher Geogr. Schr. 24.

Garratt, J.R. 1992. The atmospheric boundary layer. Cambridge, etc., Cambridge University Press.

Grainger, M.E. and H. Lister. 1966. Wind speed, stability and eddy viscosity over melting ice surfaces. J. Glaciol., 6(43), 101-127.

Havens, J.M., F. Müller and G.C. Wilmot. 1965. Comparative meteorological survey and a short-term heat balance study of the White Glacier, Canadian Arctic Archipelago — summer 1962. Montréal, McGill University. (Axel Heiberg Island Research Reports. Meteorology 4.

Hay, J.E. and B.B. Fitzharris. 1988. A comparison of the energybalance and bulk-aerodynamic approaches for estimating glacier melt. J. Glaciol., 34(117), 145-153.

Henneken, E. A. 1994. On the use of the profile method on the Greenland ice sheet. Gronlands Geologiske Undersegelse, Ser. Open Fïle, $94(13), 57-59$.

Hogg, I. G. G., J. G. Paren and R.J. Timmis. 1982. Summer heat and ice balances on Hodges Glacier, South Georgia, Falkland Islands Dependencies. J. Glaciol., 28 99), 221-238.

Högström, U. 1988. Non-dimensional wind and temperature profiles in the atmospheric surface layer: a re-evaluation. Boundary-Layer Meleorol., 42, 55-78.

Hoinkes, H. C. 1953. Wärmeumsatz und Ablation auf Alpengletschern. II. Hornkees (Zillertaler Alpen), September 1951. Geogr. Ann., 35 (2), $116-140$.

Hoinkes, H. C. and N. Untersteiner. 1952. Wärmeumsatz und Ablation auf Alpengletschern. I. Vernagtferner (Ötztaler Alpen), August 1950. Geogr. Ann., 34(1-2), 99-158.

Holmgren, B. 1971. Climate and energy exchange on a sub-polar ice cap in summer. Arctic Institute of North America Devon Island Expedition 19611963. Part C. On the katabatic winds over the north-west slope of the ice cap. Variations of the surface roughness. Uppsala, Uppsala Universitet. (Meteorologiska Institutionen. Meddelande 109.)

Keeler, C. M. 1964. Relationship between climate, ablation and run-off on the Sverdrup Glacier, 1963, Devon Island, N.W.T. Montréal, Arctic Institute of North America. (AINA Research Paper 27.)

King, J. C. and P. S. Anderson. 1994. Heat and water vapour fluxes and scalar roughness lengths over an Antarctic ice shelf. Boundary Layer Meteorol., 69 (1-2), 101-121.

Kraus, H. 1973. Energy exchange at air-ice interface. International Association of Hydrological Sciences Publication 107 (Symposium at Banff 1972 - The Role of Snow and Ice in Hydrology, Vol. 1), 128-164.

Kraus, H. 1975. An energy balance model for ablation in mountainous areas. International Association of Hydrological Sciences Publication 104 (Symposium at Moscow 1971 - Snow and Ice), $74-82$.

Kuhn, M. 1979. On the computation of heat transfer coefficients from energy-balance gradients on a glacier. 7. Glaciol., 22(87), 263-272.

Kuhn, M. 1987. Micro-meteorological conditions for snow melt. J. Glaciol., 33(113), 24-26.

Lister, H. and P.F. Taylor. 1961. Heat balance and ablation on an Arctic glacier. Medd. Gronl., $158(7)$.

Martin, S. 1975. Wind regimes and heat exchange on Glacier de SaintSorlin. f. Glaciol., $14(70), 91-105$.

Meesters, A. G. C. A., E. A. C. Henneken, N. J. Bink, H. F. Vugts and F. Cannemeijer. 1994. Simulation of the atmospheric circulation near the Greenland ice sheet margin. Global and Planetary Change, 9(1-2), $53-67$.

Moore, R.D. 1983. On the use of bulk aerodynamic formulae over melting snow. Nord. Hydrol., 14(4), 193-206.

Moore, R. D. and I. F. Owens. 1984. Controls on advective snowmelt in a maritime alpine basin. J. Climate Appl. Meteorol., 23(1), 135-142. 
Morris, E. M. 1989. Turbulent transfer over snow and ice. 7. Hydrol., 105, 205-223.

Morris, E. M. and R.J. Harding. 1991. Parameterization of turbulent transfers between glaciers and the atmosphere. International Association of Hydrological Sciences Publication 208 (Symposium at St. Petersburg 1990 - Glaciers-Ocean-Atmosphere Interactions), 543-549.

Munro, D.S. 1989. Surface roughness and bulk heat transfer on a glacier: comparison with eddy correlation. F. Glaciol., 35 (121), 343348.

Munro, D.S. 1990. Comparisons of melt energy computations and ablatometer measurements on melting ice and snow. Arct. Alp. Res., $22(2), 153-162$.

Munro, D.S. and J.A. Davies. 1977. An experimental study of the glacier boundary layer over melting ice. J. Glaciol., 18 80), 425-436.

Obukhov, A.M. 1971. Turbulence in an atmosphere with a nonuniform temperature. Boundary-Layer Meteorol., 2, 7-29.

Oerlemans, J. 1991. The mass balance of the Greenland ice sheet: sensitivity to climate change as revealed by energy-balance modelling. Holocene, $\mathbf{1}(1), 40-49$.

Oerlemans, J. 1992. Climate sensitivity of glaciers in southern Norway: application of an energy-balance model to Nigardsbreen, Hellstugubreen and Alfotbreen. F. Glaciol, 38 (129), 223-232.

Oerlemans, J. and J. P. F. Fortuin, 1992. Sensitivity of glaciers and small ice caps to greenhouse warming. Science, 258 (5079), 115-117.

Oerlemans, J. and N. C. Hoogendoorn. 1989. Mass-balance gradients and climatic change. F. Glaciol., 35 121), 399 405.

Oerlemans, J. and H.F. Vugts. 1993. A meteorological experiment in the melting zone of the Greenland ice sheet. Bull. Am. Meteorol. Soc., 74(3), 355-365.

Ohmura, A. and 6 others. 1994. Energy balance for the Greenland ice sheet by observation and model computation. International Association of Hydrological Sciences Publication 223 (Symposium at Yokohama 1993 - Snow and Ice Covers: Interactions with the Almosphere and Ecosystems), $85-94$.

Oke, T. R. 1978. Boundary layer climates. First edition. London, Methuen Publishing Co.

Panofsky, H. A. and J.A. Dutton. 1984. Atmospheric turbulence: models and methods for engineering applications. New York, etc., John Wiley.

Paterson, W. S. B. 1969. The physics of glaciers. First edition. Oxford, etc., Pergamon Press,

Paterson, W. S. B. 1994. The physies of glaciers. Third edition. Oxford, etc., Pergamon Press.

Plüss, C. and R. Mazzoni. 1994. The role of turbulent heat fluxes in the energy balance of high Alpine snow cover. Nord. Hydrol., 25 (1-2), 25 38.

Poggi, A. 1977. Heat balance in the ablation area of the Ampère Glacier (Kerguelen Islands). \%. Appl. Meteorol., 16 1), 48-55.

Price, A.G. and T. Dunne. 1976. Energy balance computations of snowmelt in a subarctic area. Water Resour. Res., 12 4), 686-694.

Skeib, G. 1962. Zum Strahlungs- und Wärmehaushalt des Zentralen Tujuksu-Gletschers im Tienschan-Gebirge. Z. Meteorol., 16(1-2), $1-9$.

Streten, N. A. and G. Wendler, 1968. The midsummer heat balance of an Alaskan maritime glacier. J. Glaciol., 7 (51), 431-440.

Sverdrup, H. U. 1935. Scientific results of the Norwegian-Swedish Spitsbergen Expedition in 1934. Part IV. The ablation on Isachsen's Plateau and on the Fourteenth of July Glacier in relation to radiation and meteorological conditions. Geogr. Ann., 17 (3-4), 145-166.

Untersteiner, N. 1957. Glazial-meteorologische Untersuchungen im Karakorum. II. Wärmehaushalt. Arch. Meteorol., Geophys. Bioklim., Ser. $B, \mathbf{8}(2), 137-171$.

Wal, R. S. W. van de and A.J. Russell. 1994. A comparison of energy balance calculations, measured ablation and meltwater runoff near Sondre Stromfjord, West Greenland. Global and Planetary Change, 9 (12), 29-38.

Webb, E. K. 1970. Profile relationships: the log-linear range, and extensions to strong stability. Q. J. R. Meteorol. Soc., 96, 67 90.

Weisman, R. N. 1977. Snowmelt: a two-dimensional turbulent diffusion model. Water Resour. Res., 13 2), 337-342.

Wendler, G. and G. Weller. 1974. A heat-balance study on McCall Glacier, Brooks Range, Alaska: a contribution to the International Hydrological Decade. J. Glaciol., 13 67), 13-26.

Wilson, W. T. 1941. An outline of the thermodynamics of snow-melt. Trans. Am. Geophys. Union, 41 (1), 182-195.

MS received 12 May 1994 and accepted in revised form 9 May 1995 